ИСПИТИВАЊЕ ПОВЕЗАНОСТИ ТЕЖИНЕ СРЦА СА РУПТУРОМ СРЦА КОД 119 СЛУЧАЈЕВА УМРЛИХ ОД АКУТНОГ ИНФАРКТА МИОКАРДА

Љиљана Кулић¹, Милан Кнежевић², Биљана Анђелски Радичевић

\title{
TESTING OF CORRELATION OF HEART WEIGHT AND HEART RUPTURE IN 119 CASES OF DECEASED OF ACUTE MYOCARDIAL INFARCTION
}

Ljiljana Kulić, Milan Knežević, Biljana Anđelski Radičević

\section{Сажетак}

Увод. Болести сриа и крвних судова представљају најчешћи узрок смрти, што показују подачи добијени у истраживанима наших и страних аутора, а акутни инфаркт миокарда је најчешће ургентно стање у интерној медицини и морталитет му је веома висок, јер од укупног морталитета једна трећина отпада на инфаркт миокарда.

Циљ рада је био да утврдимо постоји ли статистички значајна разлика у тежсини сриа код умрлих пацијената са акутним инфарктом миокарда (АИМ) са руптуром сриа и са АИМ-ом без руптуре сриа.

Методе. Истраживачки материјал чини 119 обдукованих пачијената у Институту за патологију Медицинског факултета у Крагујевиу и КБЦ Крагујеваи. Примењене су патолошко морфолошке методе истраживаға: обдукиија, макроскопска дијагностика и микроскопска анализа. Поред тога, вриена је статистичка обрада резултата, а за тестирање значајности разлика коришћен је Студентов тест софтверски пакет статистичких тестова Pharmocologic Circulapon Sistem. Kaо статистички значајна сматрана је разлика ако је $p<0,05$ и високо значајна ако је $p<0,01$.

Резултати и дискусија. Од 119 случајева умрлих од АИМ-а, од чега је 74 мушкариа и 45 жена, руптура сриа нађена је у 21 случају.

\section{Summary}

Introduction. Cardiovascular and blood vessel diseases are the most common cause of death, which is shown by data obtained in our and foreign authors' research, and acute myocardial infarction is the most common emergency in internal medicine and its mortality is very high, about one third of total mortality.

The aim of this paper is to determine whether there is a statistically significant difference in heart weight in deceased patients with acute myocardial infarction (AMI) with heart rupture and with AMI without heart rupture.

Methods. The research material is made up of 119 autopsied patients at the Institute of $\mathrm{Pa}$ thology of the University of Kragujevac Medical Faculty and Clinical Center Kragujevac. The following pathological morphological research methods were applied: autopsy, macroscopic diagnostics and microscopic analysis. In addition, a statistical processing of results was performed, and the Pharmocologic Circulapon System Student's t-test statistical software package was used to test the significance of differences. A value of $p<0.05$ was considered as a statistically significant difference, and a value of $p<0.01$ as highly significant.

Results and Discussion. Out of 119 cases of AMI deaths, of which 74 male and 45 female, heart rupture was found in 21 cases. Of the 74 men who died of AMI, 13 had a rupture, and of the 45 women who died of AMI, 8 had a rupture.

\footnotetext{
${ }^{1}$ Доц. др Љиљана Кулић, Универзитет у Приштини, Медицински факултет, Косовска Митровица.

${ }^{1}$ Проф. др Милан Кнежевић, Универзитет у Крагујевцу, Медицински факултет, Институт за патологију, Крагујевац.

3 Прим. мр сц. Биљана Анђелски Радичевић, дипл. фарм., спец. медицинске биохемије, Стоматолошки факултет Универзитета у Београду, Београд, Србија.
} 
Од 74 мушкарияа који су умрли од АИМ-а, 13 је имало руптуру, а од 45 жена које су умрле од АИМ-а, осам је имало руптуру. Мерена је тежина сриа код сваког испитаника који је умро од АИМ-а $u$ испитивана повезаност тежине сриа са руптуром. Испитивање је показало да постоји статистички значајна разлика $(p<0,05)$ у просечној тежини сриа између обдукованих који су имали и оних који нису имали руптуру срияа и да је значајно теже срие оних који нису имали руптуру сриа. Испитивање је показало да постоји статистички значајна разлика $(p<0,05)$ y просечној тежини сриа између обдукованих мушкараца који су имали и оних који нису имали руптуру сриа. Значајно је теже срие оних мушкараща који нису имали руптуру срияа. Нема статистички значајних разлика ( $>>0,05)$ у просечној тежини сриа између обдукованих жена које су имале и оних које нису имале руптуру срия.

Закључак. Испитивање је показало разлику у тежсини сриа између обдукованих који су имали и оних који нису имали руптуру срияа и да је значајно теже срие оних који нису имали руптуру сриа. У односу на пол значајно је теже срие оних мушкараца који нису имали руптуру сриа, док код жена нема статистички значајних разлика $(p>0,05)$ у просечној тежини срияа код оних са и без руптуре сриа.

Кључне речи: инфаркт миокарда, руптура срияа, тежина срияа.
The heart weight was measured in each respondent who died of AMI and the correlation between heart weight and rupture was investigated. The study showed that there was a statistically significant difference $(p<0.05)$ in the average heart weight between the autopsied who had and those who did not have heart rupture, and that those who did not have heart rupture had significantly more heart weight. The study showed that there was a statistically significant difference $(p<0.05)$ in the average heart weight between the autopsied men who had and those who did not have heart rupture. The heart of those men who did not have heart rupture had more weight. There were no statistically significant differences $(p>0.05)$ in the mean heart weight between the autopsied women who had and those who did not have heart rupture.

Conclusion. The study showed the difference in the heart weight of autopsied patients who had and those who did not have heart rupture, and that those who did not have heart rupture had significantly more heart weight. In relation to sex, the heart of those men who did not have heart rupture had more weight, while in women there are no statistically significant differences $(p>0.05)$ in the average heart weight in those with and without rupture of the heart.

Keywords: myocardial infarction, heart rupture, heart weight.

\section{УВОД}

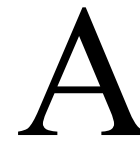
кутни инфаркт миокарда је најчешће ургентно стање у интерној медицини и морталитет му је веома висок, јер од укупног морталитета једна трећина отпада на инфаркт миокарда. У Србији годишње од свих узрока смрти умре приближно 100.000 људи и готово сваки други становник Србије умре од болести срца и крвних судова. Анализа морбидитета одраслог ста- новништва у Србији по групама болести показује да ова популација најчешће оболева од болести кардиоваскуларног система, малигних болести и болести респираторног система, по подацима Института за јавно здравље Србије „Др Милан Јовановић Батут“, који су садржани у Здравственостатистичком годишњаку Републике Србије за 2011. годину. Епидемиолошка анализа морбидитета и морталитета од кардиоваскуларних болести у Србији у периоду 
2001-2011. године показује да: број умрлих од свих узрока смрти расте; број умрлих од кардиоваскуларних болести расте; број умрлих од исхемијског обољења срца расте; број умрлих од акутног инфаркта миокарда расте.

\section{ЦИЉ РАДА}

Циљ рада је се процени повезаност тежине срца са руптуром срца код 119 случајева умрлих од акутног инфаркта миокарда. Испитати могућност корелације између руптуре срца и тежине срца у односу на пол (мушки и женски) и независно од пола обдукованих испитаника.

\section{МАТЕРИЈАЛ И МЕТОДЕ}

Истраживачки материјал чини 119 обдукованих пацијената у Институту за патологију Медицинског факултета у Крагујевцу и КБЦ Крагујевац, умрлих од акутног инфаркта миокарда. Обдуковани случајеви подељени су у две групе у односу на пол: мушки (74) и женски (45). Код 119 умрлих од акутног инфаркта миокарда установљено је да ли има или нема руптуре срца, мерена и тежина срца да би се проценила повезаност тежине срца са руптуром срца код 119 случајева умрлих од акутног инфаркта миокарда. Примењене су патолошко-морфолошке методе истраживања: обдукција, макроскопска дијагностика и микроскопска анализа. Резултати су статистички обрађени. Добијени резултати представљени су табеларно и/или графички, као средња вредност Астандардна девијација (СД) или као проценат промене у односу на одговарајућу компарабилну групу. За тестирање значајности разлика коришћен је Студентов Т-тест, софтверски пакет статистичких тестова Pharmocologe ic Circulapon Sistem (R.J. Tallarida и R.B. Murray, SpingerVerlag, New York, 1986). Kao статистички значајна сматрана је разлика ако је $\mathrm{p}<0,05$ и високо значајна ако је $\mathrm{p}<0,01$.

\section{РЕЗУЛТАТИ РАДА}

Укупан број од 119 испитаника, који су умрли од акутног инфаркта миокарда, подељен је у две групе у односу на пол: мушки (74) и женски (45). Код свих испитаника умрлих од акутног инфаркта миокарда испитивано је да ли има или нема руптуре срца, мерена је тежина срца и процењивана је повезаност тежине срца са руптуром срца.

Урађена је анализа обдукованих испитаника мушког пола са инфарктом миокарда према томе да ли су имали руптуру срца и према тежини срца, што илуструје Табела 1.

табела 1. Обдуковани испитаници мушког пола са инфарктом миокарда према томе да ли су имали руптуру срияа и према тежини сриза.

\begin{tabular}{|c|c|c|c|c|}
\hline \multirow{2}{*}{$\begin{array}{l}\text { Редни } \\
\text { број }\end{array}$} & \multirow[t]{2}{*}{ Обележје } & \multicolumn{2}{|c|}{ Руптура срца } & \multirow[t]{2}{*}{ Укупно } \\
\hline & & Да & He & \\
\hline 0 & 1 & 2 & 3 & 4 \\
\hline 1 & Број испитаника & 13 & 61 & 74 \\
\hline 2 & Минимална вредност тежине срца (г) & 310 & 220 & 220 \\
\hline 3 & Максимална вредност тежине срца (г) & 620 & 930 & 930 \\
\hline 4 & Просечна вредност тежине срца (г) & 446,92 & 528,03 & 513,78 \\
\hline 5 & Стандардна девијација & 94,90 & 139,71 & 135,98 \\
\hline 6 & Коефицијент варијације у \% & 21,23 & 26,46 & 26,47 \\
\hline 7 & \multicolumn{4}{|l|}{ Интервал поузданости за вероватноһу $p=0,95$} \\
\hline 8 & - доња граница & 395,33 & 492,97 & 482,80 \\
\hline 9 & - горња граница & 498,51 & 563,09 & 544,76 \\
\hline 10 & $\begin{array}{l}\text { Значајност разлика у просечној старости, } \\
\text { Т-тест }\end{array}$ & & $992 ; \mathrm{p}<$ & \\
\hline
\end{tabular}


На основу података приказаних у Табели 1, утврђено је:

1. да се тежина срца обдукованих мушкараца: са руптуром срца, креће од 310 до 620 g; без руптуре срца, креће од 220 до 930 g; свих укупно креће од 220 до $930 \mathrm{~g}$;

2. дајепросечна тежина срца обдукованих мушкараца: са руптуром срца, 446,92 \pm 94,90 g; без руптуре срца, 528,03 $\pm 139,71$ g; свих укупно 513,78 $\pm 135,98$ g;

3. да су коефицијенти варијације у свим анализираним групама болесника мањи од 30\%, па се може сматрати да су појединачни подаци међусобно хомогени и погодни за статистичка закључивања;
4. да се са вероватноћом $\mathrm{p}=0,95$ може очекивати да се у основном скупу из кога је добијен анализирани узорак просечна тежина срца обдукованих мушкараца: са руптуром срца креће од 395,3 до 498,5 g; без руптуре срца креће од 493,0 до 563,1 g; свих укупно креће од 482,8 до 544,8 g; 5. да постоји статистички значајна разлика $(\mathrm{p}<0.05)$ у просечној тежини срца између обдукованих мушкараца који су имали и оних који нису имали руптуру срца, наиме, значајно је теже срце код оних који нису имали руптуру срца.

Урађена је анализа патохистолошких налаза обдукованих испитаника женског пола са инфарктом миокарда према томе да ли су имали руптуру срца и према тежини срца, што илуструје Табела 2.

Табела 2. Обдуковани испитаници женског пола са инфарктом миокарда према томе да ли су имали руптуру сриа и према тежини сриа.

\begin{tabular}{|c|c|c|c|c|}
\hline \multirow{2}{*}{$\begin{array}{l}\text { Редни } \\
\text { број }\end{array}$} & \multirow[t]{2}{*}{ Обележје } & \multicolumn{2}{|c|}{ Руптура срца } & \multirow[t]{2}{*}{ Укупно } \\
\hline & & Да & He & \\
\hline 0 & 1 & 2 & 3 & 4 \\
\hline 1 & Број испитаника & 8 & 37 & 45 \\
\hline 2 & Минимална вредност тежине срца (г) & 300 & 300 & 300 \\
\hline 3 & Максимална вредност тежине срца (г) & 500 & 650 & 650 \\
\hline 4 & Просечна вредност тежине срца (г) & 375,00 & 432,97 & 424,88 \\
\hline 5 & Стандардна девијација & 68,34 & 72,26 & 73,79 \\
\hline 6 & Коефицијент варијације у \% & 18,22 & 16,69 & 17,37 \\
\hline 7 & \multicolumn{4}{|l|}{ Интервал поузданости за вероватноћу p=0,95 } \\
\hline 8 & - доња граница & 320,32 & 409,69 & 402,82 \\
\hline 9 & - $\quad$ горња граница & 429,68 & 456,25 & 446,94 \\
\hline 10 & $\begin{array}{l}\text { Значајност разлика у просечној старости, } \\
\text { Т-тест }\end{array}$ & \multicolumn{3}{|c|}{$\mathrm{t}=1,835 ; \mathrm{p}>0,05$} \\
\hline
\end{tabular}

На основу података приказаних у Табели 2, утврђено је:

1. да се тежина срца обдукованих жена: са руптуром срца, креће од 300 до $500 \mathrm{~g}$; без руптуре срца, креће од 300 до $650 \mathrm{~g}$; свих укупно, креће од 300 до $650 \mathrm{~g}$;

2. да је просечна тежина срца обдукованих жена: са руптуром срца, 375,00 \pm $68,34 \mathrm{~g}$; без руптуре срца, $432,97 \pm 72,26$ g; свих укупно, 424,88 $\pm 73,79$ g;
3. да су коефицијенти варијације у свим анализираним групама болесника мањи од $30 \%$, па се може сматрати да су појединачни подаци међусобно хомогени и погодни за статистичка закључивања;

4. да се са вероватноћом $p=0,95$ може очекивати да се у основном скупу из кога је добијен анализирани узорак просечна тежина срца обдукованих жена: са руптуром срца креће од 320,3 до 429,7 g; без 
руптуре срца креће од 409,7 до 456,2 g; свих укупно креће од 402,8 до 446,9 g;

5. да нема статистички значајних разлика $(\mathrm{p}>0,05)$ у просечној тежини срца између обдукованих жена које су имале и оних које нису имале руптуру срца.
Урађена је анализа патохистолошких налаза свих обдукованих испитаника са инфарктом миокарда без обзира на пол према томе да ли су имали руптуру срца и према тежини срца, што илуструје Табела 3.

Табела 3. Сви обдуковани испитаници са инфарктом миокарда према томе да ли су имали руптуру сриза и према тежини срица.

\begin{tabular}{|c|c|c|c|c|}
\hline \multirow{2}{*}{$\begin{array}{l}\text { Редни } \\
\text { број }\end{array}$} & \multirow[t]{2}{*}{ Обележје } & \multicolumn{2}{|c|}{ Руптура срца } & \multirow[t]{2}{*}{ Укупно } \\
\hline & & Да & He & \\
\hline 0 & 1 & 2 & 3 & 4 \\
\hline 1 & Број испитаника & 21 & 98 & 119 \\
\hline 2 & Минимална вредност тежине срца (г) & 300 & 220 & 220 \\
\hline 3 & Максимална вредност тежине срца (г) & 620 & 930 & 930 \\
\hline 4 & Просечна вредност тежине срца (г) & 424,21 & 492,16 & 481,11 \\
\hline 5 & Стандардна девијација & 92,09 & 127,11 & 124,34 \\
\hline 6 & Коефицијент варијације у \% & 21,71 & 25,83 & 25,84 \\
\hline 7 & \multicolumn{4}{|l|}{ Интервал поузданости за вероватноћу p=0,95 } \\
\hline 8 & - доња граница & 382,80 & 466,97 & 458,58 \\
\hline 9 & - горња граница & 465,62 & 517,31 & 503,64 \\
\hline 10 & $\begin{array}{l}\text { Значајност разлика у просечној старости, } \\
\text { Т-тест }\end{array}$ & \multicolumn{3}{|c|}{$\mathrm{t}=2,216 ; \mathrm{p}<0,05$} \\
\hline
\end{tabular}

На основу података приказаних у Табели 3, утврђено је:

1. да се тежина срца обдукованих: са руптуром срца креће од 300 до $620 \mathrm{~g}$; без руптуре срца креће од 220 до 930 g; свих укупно, креће од 220 до $930 \mathrm{~g}$;

2. да је просечна тежина срца обдукованих: са руптуром срца 424,21 $\pm 92,09 \mathrm{~g}$; без руптуре срца $492,16 \pm 127,11 \mathrm{~g}$; свих укупно, 481,11 +124,34 g;

3. да су коефицијенти варијације у свим анализираним групама болесника мањи од $30 \%$, па се може сматрати да су појединачни подаци међусобно хомогени и погодни за статистичка закључивања;

4. да се са вероватноћом $\mathrm{p}=0,95$ може очекивати да се у основном скупу из кога је добијен анализирани узорак просечна тежина срца обдукованих: са руптуром срца креће од 382,8 до 465,6 g; без руптуре срца креће од 467,0 до 517,3 g; свих укупно, креће од 458,6 до 503,6 g;
5. да постоји статистички значајна разлика $(\mathrm{p}<0,05)$ у просечној тежини срца између обдукованих који су имали и оних који нису имали руптуру срца, наиме, значајно је теже срце код оних који нису имали руптуре.

\section{ДИСКУСИЈА}

Разматрана је могућност корелације између руптуре срца и тежине срца, у односу на пол (мушки и женски) и независно од пола обдукованих испитаника. Анализом података обдукованих испитаника мушког пола са инфарктом миокарда према томе да ли су имали руптуру срца и према тежини срца констатовано је да се тежина срца обдукованих мушкараца са руптуром срца креће од 310 до $620 \mathrm{~g}$, без руптуре срца креhе се од 220 до $930 \mathrm{~g}$, а за све укупно без обзира на постојање руптуре тежина срца се креће од 220 до 930 g. Установљено је да је просечна тежина срца обдукованих мушкараца са руптуром срца 446,92 $\pm 94,90$ 
$\mathrm{g}$, без руптуре срца 528,03 + 139,71 g, и за све укупно без обзира на постојање руптуре $513,78+135,98$ g. Коефицијенти варијације у свим анализираним групама болесника мањи су од $30 \%$, те се може сматрати да су појединачни подаци међусобно хомогени и погодни за статистичка закључивања. Са вероватноћом $\mathrm{p}=0,95$ се може очекивати да се у основном скупу из кога је добијен анализирани узорак просечна тежина срца обдукованих мушкараца са руптуром срца креће од 395,3 до 498,5 g, без руптуре срца креће од 493,0 до 563,1 g, а за све укупно без обзира на руптуру срца, просечна тежина срца се креће од 482,8 до 544,8 g. Установљено је да постоји статистички значајна разлика $(p<0,05)$ у просечној тежини срца између обдукованих мушкараца који су имали и оних који нису имали руптуру срца. Значајно је теже срце код оних који нису имали руптуру срца. Ови резултати су добијени и у неким другим истраживањимa. $^{(1,2.3,4)}$

Урађена је анализа патохистолошких налаза обдукованих испитаника женског пола са инфарктом миокарда према томе да ли су имали руптуру срца према тежини срца. Констатовано је да се тежина срца обдукованих жена са руптуром срца креће од 300 до $500 \mathrm{~g}$, без руптуре срца креће од 300 до $650 \mathrm{~g}$, а за све укупно без обзира на руптуру срца креће од 300 до 650 g. Просечна тежина срца обдукованих жена са руптуром срца је $375,00 \pm 68,34 \mathrm{~g}$, без руптуре срца $432,97 \pm 72,26 \mathrm{~g}$, а за све укупно без обзира на руптуру срца $424,88 \pm 73,79$ g. Коефицијенти варијације у свим анализираним групама болесника мањи су од $30 \%$, па се може сматрати да су појединачни подаци међусобно хомогени и погодни за статистичка закључивања. Утврђено је да се са вероватноћом $\mathrm{p}=0,95$ може очекивати да је у основном скупу из кога је добијен анализирани узорак просечна тежина срца обдукованих жена са руптуром срца од 320,3 до $429,7 \mathrm{~g}$, без руптуре срца од 409,7 до 456,2 $\mathrm{g}$ и без обзира на руптуру срца просечна тежина срца креће се од 402,8 до 446,9 g.
Утврђено је да нема статистички значајних разлика (p>0,05) у просечној тежини срца између обдукованих жена које су имале и оних које нису имале руптуру срца, што се слаже са резултатима других аутора. ${ }^{(5,6)}$

Урађена је, такође, анализа патохистолошких налаза обдукованих испитаника према томе да ли су имали руптуру срца и према тежини срца овога пута без обзира на пол испитаника. Констатовано је да се тежина срца обдукованих са руптуром срца креће од 300 до $620 \mathrm{~g}$; без руптуре срца од 220 до 930 g; а за све укупно без обзира на постојање руптуре срца креће се од 220 до 930 g. Просечна тежина срца обдукованих са руптуром срца је 424,21 $\pm 92,09$ g, без руптуре срца $492,16 \pm 127,11 \mathrm{~g}$ и за све укупно без обзира на постојање руптуре срца $481,11 \pm 124,34$ g. С обзиром на то да су коефицијенти варијације у свим анализираним групама болесника мањи од $30 \%$, може се сматрати да су појединачни подаци међусобно хомогени и погодни за статистичка закључивања. Утврђено је да се са вероватноћом $\mathrm{p}=0,95$ може очекивати да је у основном скупу из кога је добијен анализирани узорак просечна тежина срца обдукованих са руптуром срца креће од 382,8 до 465,6 g, без руптура срца креће од 467,0 до 517,3 g и за све укупно без обзира на постојање руптуре просечна тежина срца је од 458,6 до 503,6 g. Нађена је статистички значајна разлика $(\mathrm{p}<0,05)$ у просечној тежини срца између обдукованих који су имали и оних који нису имали руптуру срца. Наиме, значајно је теже срце оних који нису имали руптуру срца. Наведено се слаже са резултатима других аутора. ${ }^{(7,8,9,10)}$

\section{ЗАКЉУУАК}

Испитивање је показало да постоји статистички значајна разлика $(\mathrm{p}<0,05)$ у просечној тежини срца између обдукованих који су имали и оних који нису имали руптуру срца и да је значајно теже срце оних који нису имали руптуру срца. У односу на пол значајно је теже срце оних мушкара- 
ца који нису имали руптуру срца, док код жена нема статистички значајних разлика $(\mathrm{p}>0,05)$ у просечној тежини срца код оних са и без руптуре срца.

\section{ЛИТЕРАТУРА}

1. Азањац C, Кнежевић M, Кањух В, Кнежевић J, Држајић В, Анђелковић 3, Станковић В, Велимировић Д, Јанчић С. Инфаркт миокарда (патолошкоморфолошке карактеристике у 111 обдукованих болесника). Зборник радова VI Конгреса патолога Југославије, Златибор, 1994; стр. 53-54.

2. Baroldi G, Falzi G, Mariani F. Sudden coronary death. A postmortem study in 208 selected cases compared to 97 control subjects. Am Heart J, 1979; 98: 20-31.

3. Cliff WJ, Heathcote CR, Moss NS, Reinchenbach DD. The coronary arteries in cases of cardiac and noncardiac sudden death. Am J Pathol, 1988; 132: 319-329.

4. Кнежевић М, Кањух В, Кнежевић J, Петров Б, Велимировић Д, Ластић Малетић С, Туцаковић Г. Relatioship between the mode of patients death and the size and wight of the myocardial infarcted area. Зборник радова VI Конгреса паталога Југославије, Златибор, 1994; стр. 51-52.

5. Кањух В, Ластић Малетић C, Станковић $Г$, Туцаковић $\Gamma$. Патолошкоморфолошка студија 204 случаја руптуре срца у току акутног инфаркта миокарда. Кардиологија, Наука, 2000; стр. 2310-2316.
6. Кулић Љ. Компаративна патоморфолошка и патохистолошка квалитативна и квантитативна анализа коронарних артерија и миокарда код атеросклеротичне коронарне болести срца. Докторска дисертација, 2001.

7. Roberts CW, Potkin NB, Solus ED, Shanthasundari GR. Mode of death, frequency of heald and acute myocardial infarction, number of major epicardial coronary arteries severly narrowed by atherosclerotic plaque, and heart weight in fatal atherosclerotic coronary artery disease: Analysis of 889 patients studied at necropsy. J. Am. Coll Cardiol. 1990; 15: 196-203. 8. Reinchenbach DD, Moss NS, Meyer E. Pathology of the heart in sudden cardiac death. Am J Cardiol, 1977; 39: 865-872. 9. Warnes AC, Roberts WC. Sudden coronary death: Relation of amount and distribution of coronary narrowing et necropsy to previous symptoms of myocardial ischemia, left ventricular scarring and heart weight. Am J Cardiol, 1984; 54: 65-73.

10. Naeim F, De la Maza LM, Robbins SL. Cardiac rupture during myocardial infarction. A review of 44 cases. Circulation, 1972; 45 (6): 1231-9.

Контакт: Доц. др Љиљана Кулић, Универзитет у Приштини, Медицински факултет, Косовска Митровица. 